\title{
Presentation of Diffuse Large B-Cell Lymphoma Relapse as a Penile Mass
}

\section{Penil Kitle ile Başvuran Diffüz Büyük B Hücreli Lenfoma Nüksü}

\author{
Birgül Öneç¹, Kürşad Öneç², Ali Ümit Esbah³, Onur Esbah4 \\ ${ }_{1}^{1}$ Düzce University Faculty of Medicine, Department of Hematology, Düzce, Turkey \\ ${ }^{2}$ Düzce University Faculty of Medicine, Department of Nephrology, Düzce, Turkey \\ ${ }^{3}$ Düzce University Faculty of Medicine, Department of Anesthesia and Intensive Care, Düzce, Turkey \\ ${ }^{4}$ Düzce University Faculty of Medicine, Department of Medical Oncology, Düzce, Turkey
}

To the Editor,

Penile malignant tumors constitute less than 1\% of all malignancies in men but penile lymphoma is even rarer in this population [1]. Presentation with a primary penile mass is extremely rare for lymphomas, as reported only in case reports in the literature $[2,3,4,5,6,7]$. Here we report a case of recurrent lymphoma presenting with a penile mass lesion.

A 51-year-old man was admitted with the appearance of swelling and ulcerations of the penis that had started 2 weeks earlier. His history revealed that he was diagnosed with stage IIIB diffuse large B-cell lymphoma (DLBCL) 7 years ago, received 6 courses of $\mathrm{R}-\mathrm{CHOP}$, and was assumed to be cured after 5 uneventful years of follow-up. Swelling at the penis increased within 2 weeks with the addition of continuous pain, superficial ulcerations, and frequent and painful urination. Physical examination revealed a diffuse and indurated swelling at the shaft of the penis with an ulcer. An enlarged left inguinal lymph node was also palpable. Magnetic resonance imaging revealed a solid lesion of $55 \times 37 \mathrm{~mm}$ in size, almost completely filling the penile corpus and significantly narrowing the penile urethra, extending to the glans penis. TruCut biopsy of the penile lesion was consistent with DLBCL. He was staged as Ann Arbor IIIE with positron emission tomographycomputed tomography revealing F-18 fluorodeoxyglucose involvement in the deep cervical left inguinal lymph nodes and a solid mass in the corpus penis (Figure 1). Treatment with R-CHOP started immediately and his complaints rapidly reduced after the first course. The patient is still having chemotherapy without

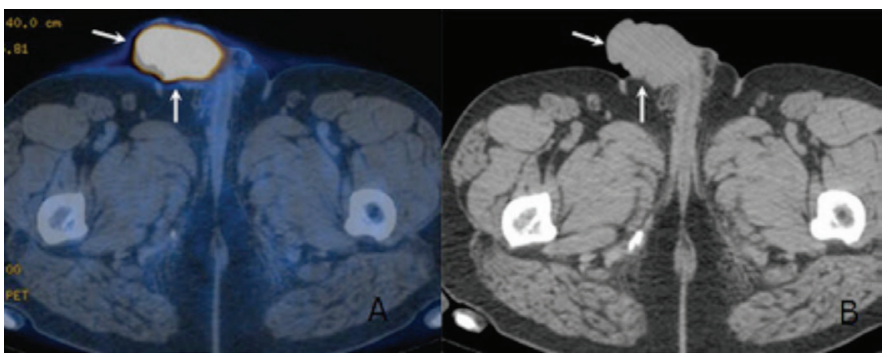

Figure 1. Transaxial fused positron emission tomographycomputed tomography (A) and computed tomography (B) images showing the penile soft tissue mass with intense F-18 fluorodeoxyglucose uptake (arrows). complications and autologous stem cell transplantation will be considered for consolidation after complete remission.

Although most DLBCL patients have nodal presentation at admission, extranodal involvements are also common. The classical extranodal involvements sites are the breast, central nervous system, and testes. Penile involvement is a rare entity reported in case reports $[2,5,7,8,9,10]$. Chu et al. reviewed penile lymphomas and reported only 48 cases, among which DLBCL was the most frequent subtype with 14 cases [5]. The most common symptom of penile lymphoma was a painless mass lesion or nodule in the penis followed by ulcerations $[5,7]$.

Surgery remains the best approach for penile cancers, whereas no standard treatment modality has been established for penile lymphomas. Systemic chemotherapy according to the subtype is a good treatment option because it preserves penile functions [2]. In our patient, R-CHOP therapy was initiated within 2 weeks after admission and obstructive symptoms were relieved immediately after the first course. Disease-free survival was reported to be between 6 and 48 months in previous case series [5], clearly indicating better outcomes than in cases of metastatic carcinomas.

In conclusion, the possibility of lymphoma involvement should be kept in mind in patients admitting with penile mass lesions, especially in patients who have a history of aggressive lymphomas, in order to avoid aggressive surgical interventions. It is important to initiate systemic chemotherapy immediately in order to prevent complications related to urethra obstruction and to preserve erectile functions.

Keywords: Penis, Lymphoma, Non-Hodgkin lymphoma, Diffuse large B-cell lymphoma, Penile mass

Anahtar Sözcükler: Penis, Lenfoma, Non-Hodgkin lenfoma, Diffüz büyük $B$ hücreli lenfoma, Penil kitle

\section{Authorship Contributions}

Concept: Birgül Öneç, Kürşad Öneç, Ali Ümit Esbah, Onur Esbah; Design: Birgül Öneç, Kürşad Öneç; Data Collection or Processing: Birgül Öneç, Kürşad Öneç; Analysis or Interpretation: Birgül 
Öneç, Onur Esbah; Literature Search: Birgül Öneç, Ali Ümit Esbah; Writing: Birgül Öneç, Ali Ümit Esbah.

Conflict of Interest: The authors of this paper have no conflicts of interest, including specific financial interests, relationships, and/or affiliations relevant to the subject matter or materials included.

\section{References}

1. Schniederjan SD, Osunkoya AO. Lymphoid neoplasms of the urinary tract and male genital organs: a clinicopathological study of 40 cases. Mod Pathol 2009;22:1057-1065.

2. Stamatiou K, Pierris N. Lymphoma presenting as cancer of the glans penis: a case report. Case Rep Pathol 2012;2012:948352.

3. Gentile G, Broccoli A, Brunocilla E, Schiavina R, Borghesi M, Romagnoli D, Bianchi L, Derenzini E, Agostinelli C, Franceschelli A, Colombo F, Zinzani $\mathrm{PL}$. An isolated penile mass in a young adult turned out to be a primary marginal zone lymphoma of the penis. A case report and a review of literature. Anticancer Res 2013;33:2639-2642.
4. Gong Z, Zhang $Y$, Chu $H$, Lian $P$, Zhang L, Sun $P$, Chen J. Priapism as the initial symptom of primary penile lymphoma: a case report. Oncol Lett 2014;8:1929-1932.

5. Chu L, Mao W, Curran Vikramsingh K, Liu X, Qiu HM, Zheng JH, Wang Y, Yu GP, Xu Q. Primary malignant lymphoma of the glans penis: a rare case report and review of the literature. Asian J Androl 2013;15:571-572.

6. Karki K, Mohsin R, Mubarak M, Hashmi A. Primary Non-Hodgkin's lymphoma of penis masquerading as a non-healing ulcer in the penile shaft. Nephrourol Mon 2013;5:840-842.

7. Wang GC, Peng $B$, Zheng JH. Primary penile malignant lymphoma: report of a rare case. Can Urol Assoc J 2012;6:E277-279.

8. Marks D, Crosthwaite A, Varigos G, Ellis D, Morstyn G. Therapy of primary diffuse large cell lymphoma of the penis with preservation of function. $J$ Urol 1988;139:1057-1058.

9. Kim HY, Oh SY, Lee $\mathrm{S}$, Lee DM, Kim SH, Kwon HC, Hong SH, Yoon JH, Kim HJ. Primary penile diffuse large B cell lymphoma treated by local excision followed by rituximab-containing chemotherapy. Acta Haematol 2008;120:150-152.

10. Jabr Fl. Recurrent lymphoma presenting as a penile ulcer in a patient with AIDS. Dermatol Online J 2005;11:29.

\title{
Successful Treatment of Disseminated Fusariosis with the Combination of Voriconazole and Liposomal Amphotericin B
}

\author{
Vorikonazol ve Lipozomal Amphoterisin B ile Başarıyla Tedavi Edilen Dissemine \\ Fusariosis Olgusu
}

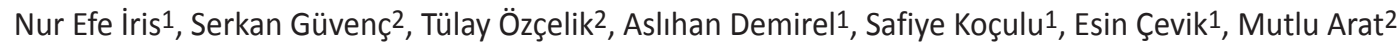 \\ 1istanbul Bilim University Faculty of Medicine, Department of Infectious Diseases and Clinical Microbiology, Istanbul, Turkey \\ 2istanbul Bilim University Faculty of Medicine, Department of Hematology, istanbul, Turkey
}

To the Editor,

Fusarium species are important causes of disseminated infections in patients with prolonged, severe neutropenia. Clinical presentation includes refractory fever, skin lesions, and sinopulmonary infections [1,2]. Disseminated Fusarium infection (DFI) carries a poor prognosis, which is related to the angiotropism of Fusarium and its capacity for adventitious sporulation in tissues [3] and resistance to many antifungal agents [4].

Here we report a hematopoietic stem cell transplant (HSCT) recipient with acute myeloid leukemia (AML) and disseminated fusariosis who was successfully treated using both liposomal amphotericin B and voriconazole.
A 24-year-old male patient underwent allogeneic HSCT from his HLA-matched brother for AML in the first remission. At 21 months after HSCT he had extramedullary relapse with a mass over his humerus. He received radiotherapy plus the FLAG-IDA salvage regimen. After 4 months, medullary relapse occurred.

When he was hospitalized for the medullary relapse, he received clofarabine with ARA-C, which caused severe neutropenia and fever. According to in-house protocol for neutropenia, piperacillin-tazobactam was initiated. However, on the third day, he was still febrile and neutropenic, so treatment was changed to meropenem and 2 days later amikacin was added. Because of hypotension, we broadened the spectrum with vancomycin. He was still febrile and he had rectal carbapenemresistant Klebsiella pneumoniae colonization. Antibiotherapy was reordered with colistin plus meropenem and vancomycin. 